\title{
Assessment of knowledge, attitude and practice towards post exposure prophylaxis for HIV among health care workers in Gondar, North West Ethiopia
}

\author{
Biniam Mathewos ${ }^{1 *}$, Wubet Birhan², Sebesbe Kinfe ${ }^{2}$, Meaza Boru², Gemechu Tiruneh², Zelalem Addis ${ }^{3}$ \\ and Agersew Alemu ${ }^{4}$
}

\begin{abstract}
Background: HIV/AIDS infection in health care facility has become a major health problem. Especially in resource poor setting health care workers are managing huge number of HIV infected patients that made them to be more exposed to HIV infection. This situation makes the use of post exposure prophylaxis for HIV very important.

Therefore the aim of the study was to assess knowledge, attitude and practice of health care workers towards post exposure prophylaxis for HIV.

Methods: Cross-sectional study was conducted among 195 health care workers from February 15 to June 20, 2012. Data was collected using self-administered questionnaire and entered and analyzed using SPSS-20 version. Results were summarized in percentages and presented in tables.

Results: Significant proportions of respondents, 72 (36.9\%), were found to have inadequate knowledge about post exposure prophylaxis for HIV. However the majority of respondent 147 (75.4\%) had good attitude toward the PEP and significant number of the respondents, 66 (33.8\%), had been exposed to blood, body fluids, needles or sharp objects once or more times while giving care for patients. Among these exposed, 49 (74.2\%) took PEP but the rest 17 (25.7\%) didn't take PEP. From these exposed respondents that took PEP, 23 (46.9\%) correctly started taking of PEP at exact initiation time, but the rest started after the recommended initiation time. Among those who took PEP, 39 (79 .6\%) completed taking the drug, however 10 (20.4\%) didn't complete the PEP regimen.

Conclusion: As a conclusion, significant proportion of study subjects had less knowledge and practice even though the majority of respondents had favorable attitude towards PEP. Therefore, a formal training for all HCWs regarding PEP for HIV and also establishing a 24 hour accessible formal PEP centre with proper guideline is recommended.
\end{abstract}

Keywords: Health care workers, Post exposure prophylaxis, HIV

\section{Background}

In order to prevent transmission of pathogens after potential exposure and also to refer for comprehensive management to minimize the risk of infection after potential exposure to HIV, post exposure prophylaxis (PEP) is needed [1]. PEP includes first aid, counseling, risk

\footnotetext{
* Correspondence: fikirbinny@gmail.com

'Department of Immunology and Molecular Biology, School of Biomedical and Laboratory Sciences College of Medicine and Health Sciences, University of Gondar, Gondar, Ethiopia

Full list of author information is available at the end of the article
}

assessment, relevant laboratory investigations based on the informed consent of the exposed person and source and following the risk assessment, provision of short term of antiretroviral drugs for 28 days, along with follow-up evaluation [2].

Health care workers (HCWs) are persons working in health care setting and they are potentially exposed to infectious materials such as blood, tissue, specific body fluids, medical supplies, equipment or environmental surfaces contaminated with these substances [2]. They are frequently exposed to occupational hazards through per-

\section{Biomed Central}

(c) 2013 Mathewos et al.; licensee BioMed Central Ltd. This is an Open Access article distributed under the terms of the Creative Commons Attribution License (http://creativecommons.org/licenses/by/2.0), which permits unrestricted use, distribution, and reproduction in any medium, provided the original work is properly cited. 
cutaneous injury such as needle stick or cut with sharps, contact with the mucus membrane of eyes or mouth of an infected person, contact with non intact skin exposed with blood or other potentially infectious body fluids [3].

When we focus on HCWs that are found in developing countries, they are at serious risk of infection from blood borne pathogens like HIV, Hepatitis B and C viruses because of the high prevalence and increased occupational risk of these pathogens in the areas $[4,5]$. Unsafe practices like careless handling of contaminated needles, unnecessary injections on demand, reuse of inadequately sterilized needles, and improper disposal of hazardous waste (major problem in developing countries) can increase the potential risk of occupational transmission of these blood borne pathogens [6].

Different evidences showed that there is an information gap in the health care setups regarding PEP. For instance a study conducted in London indicated that only $22 \%$ of doctors identified all the three drugs that are recommended at that time [7]. A study conducted in Ethiopia, Jimma town, showed that $83.9 \%$ of total HCWs had inadequate knowledge about PEP for HIV and among the exposed respondents, $81.6 \%$ did not use PEP of whom 33.8\% didn't use PEP because of lack of information [8].

In Gondar, there is no study conducted about PEP for HIV on HCWs. Thus, this study was undertaken to assess knowledge, attitude, and practice about HIV post exposure prophylaxis among health care workers of Gondar University Hospital, Gondar, and Northwest Ethiopia.

\section{Methods}

\section{Study design and area}

Cross sectional study was conducted from February 15 to June 20, 2012 among health care workers of Gondar university hospital. Gondar town is one of the oldest and historical places located $738 \mathrm{~km}$ to the North West of Addis Ababa. Gondar University Hospital is a tertiary level referral hospital that serves more than 5 million people in and around Gondar town. It has more than 500 beds with one intensive care unit.

\section{Sample size and sampling technique}

The sample size was determined by using single proportion formula $\left(\mathrm{n}=[\mathrm{Z} \alpha / 2]^{2} \mathrm{P}(1-\mathrm{p}] / \mathrm{d}^{2}\right)$ at $95 \%$ confidence interval, where, $\mathrm{Z} \alpha / 2=1.96, \mathrm{P}=$ prevalence of $50 \%$ was taken since there is no similar study in the study area and $d=5 \%$ of marginal error was taken. Using this calculation, we obtained 384 to be the sample size. Since the exact number of source population of respondent is less than 10,000, we used correction formula of $\mathrm{nf}=\mathrm{ni}$ / $(1+\mathrm{ni} / \mathrm{N})$ where $\mathrm{nf}=$ corrected sample size $\mathrm{ni}=$ uncorrected sample size, and $\mathrm{N}=$ total number of all the source population [9]. Therefore, $(384 / /(1+384 / 400=195)$, we obtained sample size of 195 .
The total sample size was distributed proportionally across different health professionals involved in this study and the study subjects were selected using simple random sampling technique.

\section{Data collection}

Structured self administered questionnaire having the common sociodemographic characteristics and questions that can assess the levels of their knowledge, attitude and practice towards PEP for HIV was prepared in English version by the research team. Then it was translated into the Amharic, local language of the study area by linguistic professionals. Matching was made on the exact fitness of the two versions. A pretest using the questionnaire was conducted among fifteen percent of the total sample size that is not to be included in the study. The pretest as well as the study was done by trained data collectors and any ambiguous and unsuitable questions were modified after the pretest had been conducted.

\section{Scoring of knowledge, attitude and practice}

Eight questions, with "Yes" (for correct answers) or "No" (for incorrect answers) response, were prepared to assess the knowledge of respondents about PEP for HIV and those respondents who scored greater than or equal to $70 \%$ were considered knowledgeable. A seven item question was used to assess participants' attitude towards PEP for HIV and those who score $70 \%$ and above were considered as having good attitude. To assess the practice of respondents' seven questions were prepared and those who answered "Yes" to more than $70 \%$ of the questions were considered as if they are practicing PEP for HIV.

\section{Data analysis}

Data was entered, cleaned and analyzed using SPSS version 20 computer software. Results were summarized in frequencies and percentages and presented in tables.

\section{Ethical consideration}

The study secured ethical clearance from ethical committee of School of Biomedical and Laboratory Science in the University of Gondar.The HCWs were registered to participate in the study only after they obtained explanation about the objectives of the study and also we obtained written consents from study participants. Confidentiality of the study subjects was maintained.

\section{Results}

\section{Sociodemographic characteristics}

A total of 119 (61\%) males and 76 (39\%) females responded in this study. Most of respondents 134 (68.7\%) were in the age group 20 to 30 years. Regarding year of service of HCWs, 83 (42.6\%), 71(34\%), 12 (9.2\%), 23 (10.8\%) served 
for 6 month- 2 years, 3-5 years, $6-8$ years more than 8 years respectively (Table 1 ).

\section{Knowledge level of the HCWs about PEP for HIV}

In general, majority, 123 (63.1\%), of the participants of the study had adequate knowledge about PEP for HIV. The proportion of respondent who heard about PEP of HIV from formal training was 95 (48.7\%). From the study participants 118 (60.5\%) answered that PEP for HIV is efficient and 99 (50.7\%) knew when to initiate PEP for HIV. One hundred and forty one $(72.3 \%)$ of the respondents knew the maximum acceptable delay to take PEP for HIV and $142(72.8 \%)$ knew for how long exposed individuals should be on PEP to prevent infection (Table 2).

Table 1 Sociodemographic characteristics of HCWs in Gondar University Hospital, 2012

\begin{tabular}{|c|c|c|}
\hline Variables & & $\mathrm{N}(\%)$ \\
\hline \multirow[t]{4}{*}{ Age of respondents } & 20-30 year & $134(61.0)$ \\
\hline & $31-40$ year & $42(21.5)$ \\
\hline & 41-50 year & $15(7.7)$ \\
\hline & $>50$ & $4(2.1)$ \\
\hline \multirow[t]{2}{*}{ Sex } & Male & $119(61)$ \\
\hline & Female & $76(39)$ \\
\hline \multirow[t]{4}{*}{ Work experience } & 6 month- 2 years & $83(42.6)$ \\
\hline & 3-5 years & $71(36.4)$ \\
\hline & 6-8 year & $18(9.2)$ \\
\hline & $>8$ year & $23(11.8)$ \\
\hline \multirow[t]{4}{*}{ Marital status } & Married & $53(27.2)$ \\
\hline & Single & $135(69.2)$ \\
\hline & Divorced & $5(2.6)$ \\
\hline & Widowed & $2(1)$ \\
\hline \multirow[t]{4}{*}{ Religion } & Orthodox Christian & $111(56.9)$ \\
\hline & Protestant Christian & 38 (19.5) \\
\hline & Muslim & $42(21.5)$ \\
\hline & Other & $4(2.1)$ \\
\hline \multirow[t]{7}{*}{ Profession } & Medical Doctor & $55(28.2)$ \\
\hline & Nurse & $45(23)$ \\
\hline & Lab. Tech. & $46(23.5)$ \\
\hline & Health officer & $4(2)$ \\
\hline & Anesthetics & $4(2)$ \\
\hline & Midwifes & $32(16.4)$ \\
\hline & physiotherapy & $9(4.6)$ \\
\hline \multirow[t]{5}{*}{ Educational level } & Certificate & $3(1.5)$ \\
\hline & Diploma & $41(21)$ \\
\hline & First Degree & $133(68.2)$ \\
\hline & Masters Degree & $14(7.2)$ \\
\hline & Specialist & $4(2.1)$ \\
\hline
\end{tabular}

\section{Attitude of the HCWs about PEP for HIV}

Majority of the respondent, 192 (98.5\%) and 172 (88.2\%), agreed on the importance of PEP for HIV and the availability of PEP guidelines in the hospital or in their work place.

Table 2 Response of HCWs to each question that assess their knowledge about PEP in Gondar University Hospital, 2012

\begin{tabular}{|c|c|c|}
\hline Knowledge questions & Responses & $\begin{array}{l}\text { Frequency } \\
(\%)\end{array}$ \\
\hline \multirow[t]{2}{*}{ Heard about PEP } & Yes & $181(92.8)$ \\
\hline & No & $14(7.2)$ \\
\hline \multirow{6}{*}{$\begin{array}{l}\text { From what source you } \\
\text { got the information? }\end{array}$} & Training & $95(48.7)$ \\
\hline & Mass media & $10(5.1)$ \\
\hline & Friends & $63(32.3)$ \\
\hline & Journals & $6(3.1)$ \\
\hline & Other & 7 (3.6) \\
\hline & Multiple answer & $14(7.2)$ \\
\hline \multirow[t]{5}{*}{$\begin{array}{l}\text { When do you think } \\
\text { PEP should be indicated? }\end{array}$} & $\begin{array}{l}\text { When the source patient is } \\
\text { at high risk for HIV }\end{array}$ & 35 (17.9) \\
\hline & $\begin{array}{l}\text { When the patient is known } \\
\text { to be HIV positive }\end{array}$ & $54(27.7)$ \\
\hline & $\begin{array}{l}\text { When the HIV status of } \\
\text { the source is unknown }\end{array}$ & $29(14.9)$ \\
\hline & $\begin{array}{l}\text { For any needle stick injury } \\
\text { in the work place }\end{array}$ & $30(15.4)$ \\
\hline & Multiple answer & $47(24.1)$ \\
\hline \multirow{4}{*}{$\begin{array}{l}\text { What is the maximum } \\
\text { delay to take PEP? }\end{array}$} & 24 hour & $19(9.7)$ \\
\hline & 48 hour & $17(8.7)$ \\
\hline & 72 hour & $141(72.3)$ \\
\hline & 12 hour & $18(9.2)$ \\
\hline \multirow{4}{*}{$\begin{array}{l}\text { What is the preferable } \\
\text { time to take PEP? }\end{array}$} & Within an hour & $99(50.8)$ \\
\hline & After 6 hour of exposure & $34(17.4)$ \\
\hline & After 12 hour of exposure & $13(6.7)$ \\
\hline & After 72 hour of exposure & $49(25.1)$ \\
\hline \multirow{5}{*}{$\begin{array}{l}\text { What is the Effectiveness } \\
\text { of PEP? }\end{array}$} & $100 \%$ & $23(11.8)$ \\
\hline & $80-100 \%$ & $118(60.5)$ \\
\hline & $60-70 \%$ & $45(23.1)$ \\
\hline & $30-50 \%$ & 7 (3.6) \\
\hline & $20-30 \%$ & $2(1.0)$ \\
\hline \multirow{4}{*}{$\begin{array}{l}\text { What is the length of time } \\
\text { to take PEP? }\end{array}$} & For 28 days & $142(72.8)$ \\
\hline & For 40 days & $32(16.4)$ \\
\hline & For six moths & $18(9.2)$ \\
\hline & For life time & $3(1.5)$ \\
\hline \multirow{2}{*}{$\begin{array}{l}\text { Have you attend any } \\
\text { training about PEP? }\end{array}$} & Yes & $127(65.1)$ \\
\hline & NO & $68(34.9)$ \\
\hline \multirow{3}{*}{$\begin{array}{l}\text { Do you know about the } \\
\text { PEP guideline? }\end{array}$} & Yes & $86(44.1)$ \\
\hline & NO & $53(27.2)$ \\
\hline & I do not know & $56(28.7)$ \\
\hline
\end{tabular}


When we assessed the respondents about their belief on PEP for HIV to reduces the likelihood of being infected by HIV after being exposed, 153 (78.5\%) of them had strong believe that it can reduce the probability to be infected and also $52(26.7 \%)$ of the respondents agreed that PEP prevent further infection. The believe that PEP may be indicated for any type of sharp object injuries was also assessed among the respondents and it was observed that 57 (29.2\%) of the respondents had that believe but the majority, 89 (45.6\%), of the study participants did not agree on it and the rest of the study participants $49(25.1 \%)$ were not sure about it. Generally, the attitude of most of the respondents, 147 (75.4\%), was good whereas 48 (24.6\%) had unfavorable attitude towards PEP for HIV (Table 3).

\section{Practice status of the HCWs towards PEP for HIV}

Among all of the respondents, 66/195 (33.8\%) were exposed for HIV risky conditions and of these exposed respondents, 49/66 (74.2\%) took PEP. However, 17/66 (25.7\%) of the exposed respondent did not take PEP. Among the respondents who took PEP, 28/49 (57.1\%) reasoned out that they took PEP for their exposure to known HIV positive blood whereas, the remaining 12/49 (24.5\%), reasoned out that they became exposed to blood of HIV

Table 3 Attitude of HCWs about PEP in Gondar University Hospital, 2012

\begin{tabular}{|c|c|c|}
\hline Questions & & Frequency \\
\hline \multirow[t]{3}{*}{ Do you think PEP is Important? } & Yes & $192(98.5)$ \\
\hline & $\mathrm{NO}$ & $3(1.5)$ \\
\hline & I am not shore & - \\
\hline \multirow{3}{*}{$\begin{array}{l}\text { Do you believe that training of PEP is } \\
\text { important for a behavioral change? }\end{array}$} & Agree & $186(95.4)$ \\
\hline & Disagree & $9(4.6)$ \\
\hline & Neutral & \\
\hline \multirow{4}{*}{$\begin{array}{l}\text { Do you think there should be PEP } \\
\text { guideline in work areas? }\end{array}$} & Agree & $135(69.5)$ \\
\hline & Disagree & $13(6.7)$ \\
\hline & Strongly agree & $37(19)$ \\
\hline & No comment & $10(5.1)$ \\
\hline \multirow{3}{*}{$\begin{array}{l}\text { Do you believe PEP reduces likelihood } \\
\text { of being HIV positive }\end{array}$} & Yes & $153(78.5)$ \\
\hline & No & $28(14.4)$ \\
\hline & I am not sure & $14(7.2)$ \\
\hline \multirow{3}{*}{$\begin{array}{l}\text { Do you believe PEP to } \\
\text { prevent further infection? }\end{array}$} & Agree & $52(26.7)$ \\
\hline & Disagree & $117(60)$ \\
\hline & Partially agree & $26(13.3)$ \\
\hline \multirow{3}{*}{$\begin{array}{l}\text { How do you see the saying that PEP is } \\
\text { indicated for any type of sharp injuries }\end{array}$} & Agree & $57(29.2)$ \\
\hline & Disagree & $89(45.6)$ \\
\hline & I am not sure & $49(25.1)$ \\
\hline \multirow{3}{*}{$\begin{array}{l}\text { What is your opinion on the believe that } \\
\text { PEP is not important if the exposure is } \\
\text { not with patient blood of known HIV positive }\end{array}$} & Agree & $30(15.4)$ \\
\hline & Disagree & $142(72.8)$ \\
\hline & I am not sure & $23(11.8)$ \\
\hline
\end{tabular}

unknown status. Among all respondents who took PEP, 23 (46.9\%) correctly started taking of PEP at exact initiation time, but the rest of them start after the recommended initiation time. Furthermore, among those respondents that took PEP, 39/49 (79.5\%) had completed taking PEP correctly, but the rest 10/49 (20.4\%) had failed to complete. The reasons for the discontinuity of taking the PEP was found to be fear of its efficacy and the adverse effects $5 / 10$ (50\%), 3/10 (30\%) respectively (Table 4).

\section{Discussion}

This study assessed the knowledge, attitude and practice towards PEP for HIV among HCWs who were directly involved in care of patients in Gondar University Hospital which is located northwest of Ethiopia.

In the present study, among all study participants 92.8\% have heard about PEP for HIV. When we compare it with other study which was conducted in a tertiary hospital in Nigeria (97\%), it was found that less percentage of the study participants in the present study had been found who heard about PEP [10].

Table 4 Practice of PEP for HIV among HCW in Gondar University Hospital, 2012

\begin{tabular}{|c|c|c|}
\hline Questions & Responses & Frequency \\
\hline \multirow{3}{*}{$\begin{array}{l}\text { Ever been exposed to } \\
\text { HIV risky conditions }\end{array}$} & Yes & $66(33.8)$ \\
\hline & No & $119(61)$ \\
\hline & I do not remember & $10(5.2)$ \\
\hline \multirow[t]{2}{*}{ took PEP after exposure } & Yes & $49(74.2)$ \\
\hline & No & $17(25.7)$ \\
\hline \multirow[t]{4}{*}{$\begin{array}{l}\text { The reason respondent } \\
\text { to took the PEP }\end{array}$} & $\begin{array}{l}\text { Exposure to blood from } \\
\text { known HIV positive patients. }\end{array}$ & $28(57.1)$ \\
\hline & $\begin{array}{l}\text { Exposure to blood from patient } \\
\text { whose HIV status is unknown }\end{array}$ & $12(24.5)$ \\
\hline & Injury from any sharp objects & $6(12.2)$ \\
\hline & $\begin{array}{l}\text { Contact with patient body } \\
\text { fluids }\end{array}$ & $3(6.1)$ \\
\hline \multirow{4}{*}{$\begin{array}{l}\text { The time to start } \\
\text { taking the PEP }\end{array}$} & With in 1 hour & $23(46.9)$ \\
\hline & After 2-6 hrs of exposure & $15(30.6)$ \\
\hline & After 6-10 hrs of exposure & $10(20.4)$ \\
\hline & After 72 hrs & $1(2)$ \\
\hline \multirow{3}{*}{$\begin{array}{l}\text { A period of time that a } \\
\text { respondent take PEP }\end{array}$} & 3 days & $3(6.1)$ \\
\hline & 15 days & $7(14.3)$ \\
\hline & 28 days & $39(79.5)$ \\
\hline \multirow{2}{*}{$\begin{array}{l}\text { completed the prescribed } \\
\text { drug of PEP }\end{array}$} & Yes & $39(79.6)$ \\
\hline & No & $10(20.4)$ \\
\hline \multirow{3}{*}{$\begin{array}{l}\text { reason for discontinuation } \\
\text { of the drug }\end{array}$} & Fear of adverse effects & $3(30)$ \\
\hline & Assuming that it was enough & $2(20)$ \\
\hline & $\begin{array}{l}\text { Assuming that the drug was } \\
\text { not effective }\end{array}$ & $5(50)$ \\
\hline
\end{tabular}


Regarding when to start PEP for HIV, in the present study $50.8 \%$ of the total respondents responded stating PEP should be taken within one hour which is higher than other findings from study conducted in Mulago Hospital in Uganda with only $22.3 \%$ being sure it should be started within an hour of exposure [11]. In another study among interns, only $31.6 \%$ of respondents stated the exact time when to initiate PEP which is also lower than our report [12]. However when we observe a study conducted in Mumbay it showed that $64 \%$ of the respondent correctly stated when to start PEP in which it is greater than the present study [13]. The difference might be because of the difference on the level of awareness among the different populations. The proportion of knowledgeable participants on when to start PEP for HIV is still low because only half the respondents stated it correctly. Therefore, if the remaining $50 \%$ of the respondents exposed for HIV risky conditions, they might took PEP after very long period of time so that they will be important sources of transmitting HIV [14].

A study conducted in Zimbabwe showed that $65 \%$ of the respondents scored less than $50 \%$ of the questions regarding knowledge which was regarded as poor knowledge [15]. In the present study the percentage of the respondents with poor knowledge is $36.9 \%$ which indicated that it is better than the findings of the study conducted in Zimbabwe. However, this level of poor knowledge cannot be considered low.

In the present study, from 195 subjects, 66 (33.8\%) of the respondents have been exposed for HIV risky conditions. This finding is less than the result found in a study conducted in south India in which $74.5 \%$ of respondents were exposed [16]. However, the number of HCWs that have ever been exposed to HIV risky conditions in the present study could not be considered as low since in Italy a study indicated only $11.3 \%$ of occupational exposure which is lower than the present study [17]. Generally the difference between the present study and the others might be due to the difference in the setting.

Even though $74.2 \%$ of the exposed respondents took PEP for HIV in this study, only $60.9 \%$ of these respondents were able to complete the regimen of the drug which requires 28 days. This finding was in agreement with other study conducted in Dar es Salaam in which they showed that $40 \%$ of the respondents failed to use PEP for the full length of time prescribed [18]. However, study conducted in Gujarat showed that their respondents had better practice in this regard than our study participants in which more than $94 \%$ were able to complete the regimen [19]. This fact alerts that the practice of PEP for HIV in the study area needs improvement.

Reasons for the observed difference of findings between different research results might be due to the difference in the level of awareness between the different population, economic difference of the study population and time difference of the studies.

\section{Conclusion}

In general, the findings of this study revealed the gap that knowledge as well as practice of HCWs towards PEP for $\mathrm{HIV}$ is inadequate. Even though many of the HCWs had HIV risky exposure, the number of HCWs that were exposed but did not take the PEP for HIV cannot be considered as low. Therefore, a formal training for all HCWs regarding PEP for HIV should be provided to improve their knowledge and also establishing a 24 hour accessible formal PEP centre with proper guideline is recommended so that their practice towards utilization of PEP can be improved.

Besides, new strategies must be developed to reduce the risk of occupational exposure in health care facilities.

\section{Competing interests}

The authors declare that they have no competing interests.

\section{Authors' contributions}

BM initiates and design the study, drafted the manuscript. WB involved in data analysis and manuscript review. SK, MB, GT involved in data collection and analysis. ZA and AA participated in data analysis and manuscript review. All authors have read and approved the final manuscript.

\section{Acknowledgements}

We would like to thank the study participants for their cooperation in providing the necessary information. Great thanks go also to all data collectors for their great support.

\section{Author details}

'Department of Immunology and Molecular Biology, School of Biomedical and Laboratory Sciences College of Medicine and Health Sciences, University of Gondar, Gondar, Ethiopia. ${ }^{2}$ Department of Clinical Chemistry, School of Biomedical and Laboratory Sciences, College of Medicine and Health Sciences, University of Gondar, Gondar, Ethiopia. ${ }^{3}$ Department of Medical Microbiology, School of Biomedical and Laboratory Sciences, College of Medicine and Health Sciences, University of Gondar, Gondar, Ethiopia. ${ }^{4}$ Department of Medical Parasitology, School of Biomedical and Laboratory Sciences, College of Medicine and Health Sciences, University of Gondar, Gondar, Ethiopia.

Received: 17 December 2012 Accepted: 21 May 2013

Published: 25 May 2013

\section{References}

1. Sharma A, Marfatiya YA, Ghiya R: Post-exposure prophylaxis for HIV. Indian J Sex Trans Dis and AIDS 2007, 28:2.61-68.

2. Ministry of Health and Family Welfare: Government of India National AIDS Control Organization: Management of Occupational exposure including Post exposure prophylaxis for HIV. NewDelhi: NACO; 2009.

3. Ministry of Health and Family Welfare, Government of India National AIDS Control Organization: Antiretroviral Therapy Guidelines for HIV-infected Adults and Adolescents including.post-exposure prophylaxisnone. New Delhi: NACO; 2008.

4. Simonsen L, Kane A, Lloyd J, Zaffran M, Kane M: Unsafe injections in the developing world and transmission of blood borne pathogens: a review. Bull World Health Organ 1999, 77:789-800.

5. Kane A, Lloyd J, Kane M: Transmission of hepatitis B, hepatitis C and HIV through unsafe injections in the developing world. Bull World Health Organ 1999, 77:801-807.

6. Charles SM, Richard DP, Janine J: Risk to health care workers in developing countries. N Engl J Med 2001, 345:538-541. 
7. Khan AZ, Ducan KM, Escotet X, Miles WEA: do we need to improve awareness about HIV post exposure prophylaxis? Ann R Coll Surg Engl 2002, 84:72-73.

8. Bosena $\mathrm{T}$, Chernet $\mathrm{H}$ : assessment of HIV exposure prophylaxis among health workers of governmental health institute in jimma zone, Oromia Region, south west Ethiopia. Ethiop J.health sci 2010, 1:55-64.

9. Thrusfield M: Veterinary Epidemiology. London: Blackwell Science; 1995.

10. Owolabi RS, Alabi P, Ajayi S, Daniel O, Ogundiran A, Akande TM, Onafowokan T: Knowledge and Practice of Post Exposure Prophylaxis (PEP) against HIV Infection among Health Care Providers in a Tertiary Hospital in Nigeria. JIAPAC 2012, 11(3):179-183.

11. Alenyo R, Fualal J, Jombwe JJ: Knowledge attitude and practice of staffs towards post exposure prophylaxes for HIV infection at Mulango hospital in Uganda. East and central African J Surgery 2009, 14(2):99-102.

12. Chacko J, Isaac R: Percutaneous injuries among medical interns and their knowledge and practice of post exposure prophylaxis for HIV. Indian J Public Health 2007, 51:127-129.

13. Chogle NL, Chogle MN, Divatia JV, Dasgupta D: Awareness of postexposure prophylaxis guidelines against occupational exposure to HIV in a Mumbai hospital. M Natl Med J India 2002, 5(2):69-72.

14. Varghese GM, Abraham OC, Mathai D: Post-exposure prophylaxis for blood borne viral infections in healthcare workers. Postgrad Med J 2003, 79:324-328

15. Monera T, Ncube P: Assessment of Knowledge, Attitude and practice of health care workers on Occupational HIV post exposure prophylaxis at Zimbabwean referral hospital. J Int AIDS Soc 2012, 15(4).

16. Tetali S, Choudhury PL: Occupational exposure to sharps and splash: Risk among health care Providers in three tertiary care hospital in south india. Indian J Occup Environ Med 2006, 10(1):35-40.

17. Bandolier E: Occupational exposure to hospital employees in Italian hospitals over 5.5 years. London: AstraZeneca group; 2003.

18. Chagani MM, Manji KP, Manji MP, Sheriff FG: Healthcare workers' knowledge, attitudes, practices on post exposure prophylaxis for HIV in Dar es Salaam. Tanzania Med J 2011, 25(2):33-38.

19. Shevkani M, Kavina B, Kumar P, Purohit H, Nihalani U, Shah A: An overview of post exposure prophylaxis for HIV in health care personals: Gujarat scenario. Indian j sex transm Dis 2011, 32(1):9-13.

doi:10.1186/1471-2458-13-508

Cite this article as: Mathewos et al: Assessment of knowledge, attitude and practice towards post exposure prophylaxis for HIV among health care workers in Gondar, North West Ethiopia. BMC Public Health 2013 13:508.

\section{Submit your next manuscript to BioMed Central and take full advantage of:}

- Convenient online submission

- Thorough peer review

- No space constraints or color figure charges

- Immediate publication on acceptance

- Inclusion in PubMed, CAS, Scopus and Google Scholar

- Research which is freely available for redistribution 